Article

\title{
Hydrological Impact of Ilisu Dam on Mosul Dam; the River Tigris
}

\author{
Abdul-Sahib T. Al-Madhhachi ${ }^{1}\left(\mathbb{D}\right.$, Khayyun A. Rahi ${ }^{2, *} \mathbb{( D}$ and Wafa K. Leabi ${ }^{3}$ \\ 1 Department of Water Resources Engineering, College of Engineering, Mustansiriyah University, \\ Baghdad 10047, Iraq; a.t.almadhhachi@uomustansiriyah.edu.iq \\ 2 Department of Environmental Engineering, College of Engineering, Mustansiriyah University, \\ Baghdad 10047, Iraq \\ 3 Department of Highway and Transportation Engineering, College of Engineering, Mustansiriyah University, \\ Baghdad 10047, Iraq; wleabi@uomustansiriyah.edu.iq \\ * Correspondence: khayyun.rahi@okstate.edu
}

Received: 15 February 2020; Accepted: 25 March 2020; Published: 27 March 2020

check for updates

\begin{abstract}
The Ilisu Dam is part of the Turkish Southeastern Anatolia Project (GAP) and is the largest dam on the Tigris River in Turkey. It is located on the main river course $65 \mathrm{~km}$ upstream of the Syrian and Iraqi border. The Ilisu Dam watershed is the same as that of the Mosul Dam in Iraq. Sharing the same watershed with the Mosul Dam and located upstream, the Ilisu Dam will usurp most of the watershed and deprive the Mosul Dam of most of its current inflow. This paper presents an assessment of the hydrological impact (basically predicts changes on future inflow) of the Ilisu Dam on the Mosul Dam. The assessment is based on the worst-case scenario. The analyses that are employed include geographic information system (GIS) techniques and regression models, along with statistical analyses to numerate expected future impacts on the Mosul Dam's inflow distribution. Results reveal that the Ilisu will have a drastic impact on the inflow regime of the Mosul Dam. A reduction as high as $78 \%$ of the inflow of the Mosul Dam may occur if the operation of the Ilisu and the Cizre Dams is conducted with no consideration of downstream hydrological and environment impacts.
\end{abstract}

Keywords: Ilisu Dam; Mosul Dam; hydrological impact; GIS; Tigris River; watersheds

\section{Introduction}

\subsection{General}

The world's water resources are stressed due to high demand and limited availability. The need for drinking water, food production and environmental protection are increasing as the world population increases. Water scarcity problems are more challenging in arid and semi-arid countries such as the country of Iraq. Iraq depends heavily on the Twin Rivers; the Euphrates and the Tigris, which provide most of the water needs of the country. The two rivers are heavily regulated and controlled by the riparian countries (Turkey, Syria and Iraq). Iraq, being the downstream riparian, has the least control on its water supplies [1]. The water crisis in the Euphrates and the Tigris basins may be explained by two factors: the lack of collaboration among the riparian countries and the absence of basin-wide water resources management plans [1,2].

In 1977, Turkey's Southeast Anatolia Project "Guneydogu Anadolu Projesi in the Turkish Language" (GAP) was initiated on the upper parts of the Euphrates and Tigris basins (the upper Mesopotamia) [3-5]. Two years earlier, Turkey had constructed the Keban Dam and Syria had launched the Tabqa Dam, both on the Euphrates River. The GAP is a Turkish irrigation-agricultural scheme that includes at least 22 dams on the upper Euphrates and Tigris Rivers [6]. The most recent dam project of the GAP system is the Ilisu Dam on the Tigris River [7]. 
The Ilisu Dam is the largest dam on the Tigris River in Turkey with a storage capacity of 10.4 billion cubic meters $(\mathrm{bcm})$. The dam started operations in the summer of 2019. It is located on the main river course, $65 \mathrm{~km}$ upstream from the border line between Iraq and Syria. As described by Turkish literature, the dam is intended for a hydroelectric-power generation [7-10]. In the planning stage is another regulator dam (barrage) at Cizre that is intended for irrigation purposes. Cizre Dam is to be constructed $45 \mathrm{~km}$ downstream of the Ilisu Dam, and about $20 \mathrm{~km}$ upstream of the border-point between Syria and Iraq [11-13].

\subsection{The Watershed of the Ilisu Dam}

The Ilisu Dam, being in the upstream, will drain most of the previously constructed the Mosul Dam's watershed. The Mosul Dam is located on the Tigris River, Iraq, $80 \mathrm{~km}$ downstream from the border with Syria and Turkey [14]. The dam was completed on 1986. The storage capacity of the lake impounded by Mosul Dam is $11.11 \mathrm{bcm}$. Published research concluded that the operation of the Ilisu Dam will drastically reduce the inflow to the Mosul Dam's Reservoir [13,15].

In recent years, the Mosul Dam stability was cited as an international issue and a matter of concern within the Iraqi population. The Washington Post [16] reported that the US Army Corps of Engineers and other US Officials said that Mosul Dam is the most dangerous dam in the world, in terms of internal erosion potential of the foundation. They concluded that if a small problem on Mosul Dam occurs, failure is likely to happen. The storage level in the lake impounded by the dam was lowered since then. The lowering reached as low as $307 \mathrm{~m}$ (AMSL); only seven meters above the dead storage. The normal operation level of the lake is $330 \mathrm{~m}$ (AMSL) [17].

In 2016, the Mosul Dam Task Force (MDTF) [18] was formed from the US Army Corps of Engineers, an Italian contracting company, and the Iraqi Ministry of Water Resources (MoWR) to conduct a grouting operation and other in situ works to improve the stability of the dam. The MDTF declared in February 2020 that "crews drilled and grouted 5200 boreholes, resulting in 400,000 meters drilled and placed more than 41,000 cubic meters of grout in the Mosul Dam's foundation. The Mosul Dam's improved stability was demonstrated as its reservoir reached its sixth-highest pool of record in April 2019 and showed no signs of distress" [18].

The lack of coordination, among the riparian countries (namely, Turkey and Iraq), resulted in a situation by which Ilisu Dam was planned and designed with no consideration for the downstream beneficiaries, especially the Mosul Dam. Bosshard and Declaration [19] reported that the water flows into Iraq were significantly reduced due to the irrigation projects of the GAP. However, the hydropower projects can be used for political blackmail of Syria and Iraq [9,10]. Bosshard [19] and Yalcin and Tigrek [9] reported that the Ilisu Reservoir has a total capacity of $10.4 \mathrm{bcm}$, and a normal operating capacity of $7.46 \mathrm{bcm}$. An extra capacity of $3 \mathrm{bcm}$ for the Ilisu Reservoir is obtained when the dam operates at normal level. They found that the average streamflow of the Tigris of $15 \mathrm{bcm}$, filling the reservoir alone will absorb one half of a yearly streamflow. Bilgen [5] stated that after the Ilisu and Cizre Dams are completed, the Tigris will also be under the (Turkish) state's control.

Several researches have been discussed land use change or human interference on the river flow and magnitude of reduction in runoff [20-23]. Yihdego and Webb [20] developed modified tanh function to predict runoff in Glenelg-Hopkins catchment, western Victoria, Australia. They modeled stream flow using monthly empirical water balance models and double mass curve analysis. Yihdego and Webb [21] used the water balance model to determine how climate, river regime and lake hydrological properties affect the non-climatic/catchment modification in Lake Buninjon, Australia. Further, Yihdego et al. [22] investigated the different impacts and dimensions of the Grand Ethiopian Renaissance Dam (GERD) on the Nile River inflow on riparian countries (Ethiopia, Sudan and Egypt).

The operation capacity of the Ilisu Dam in combination with the Cizre Dam would significantly reduce flows to Syria and Iraq, especially in the summer. It should be emphasized that the only flow that Turkey committed to release is the environmental flow of $60 \mathrm{~m}^{3} / \mathrm{sec}$. Declaration et al. [13] concluded that a significant portion of the recommended minimum flow $\left(60 \mathrm{~m}^{3} / \mathrm{sec}\right)$ released from 
Ilisu during dry years would be diverted via the Cizre Dam. They stated that with full implementation of the Ilisu-Cizre projects, all the summer flow could be diverted before it crosses the international border to Iraq. Based on Bilgen [5] statement, it is likely that inflow to the Mosul Dam will be altered, interrupted and reduced.

Hence, it is required to re-evaluate the inflow regieme to the Mosul Dam Reservoir assuming the worst-case scenario. The worst case as defined by Merriam-Webster Dictionary involves, projecting, or providing for the worst possible circumstances or outcome of a given situation [24]. The worst-case scenario is a useful device when the planner has practically no control on future events. Since the future release from the Ilisu Dam is entirely controlled by Turkey and Turkey has committed no specified flow for the Mosul Dam, then the future operation of the latter must be altered to recognize the new realities. The scenario to consider is the flow that is reliable regardless of the flow release downstream of Ilisu Dam. The reliable flow comes from the reduced watershed left for the Mosul Dam Reservoir. The purpose of this paper is to evaluate the worst-case scenario inflow to the Mosul Dam. The "new" watershed is delineated and recalculated using "Arc Hydro Tools" within geographic information system (GIS) techniques. The generated inflow is based on analyzing historical flow data and the proposed regression models.

\section{Study Area, Watershed Features and Methodology}

\subsection{Study Area, Watershed Characteristics and Rainfall Distribution}

The study area is located along the Upper Tigris River, mostly, within Turkey and Iraq. The study area is bordered by $\left(36^{\circ} 25^{\prime} 09^{\prime \prime}-38^{\circ} 45^{\prime} 36^{\prime \prime}\right) \mathrm{N}$ and $\left(39^{\circ} 15^{\prime} 18^{\prime \prime}-43^{\circ} 59^{\prime} 38^{\prime \prime}\right) \mathrm{E}$. The watershed's area covers about $50,965 \mathrm{~km}^{2}$ (Figure 1). A small part of the study area is in Syria. The "Arc Hydro Tools" of the GIS was applied to delineate watersheds for the three dams (Mosul, Ilisu and Cizre). The "Arc Hydro Tools" via "Terrain Preprocessing" is employed to obtain stream definition, flow accumulation, flow direction and drainage point outlets of the catchments.

The digital elevation model (DEM) of the United States Geological Survey (USGS) [25] with grid size of $30 \times 30 \mathrm{~m}$ was employed to delineate the administrative areas, inland water, land cover and country boundaries within the study area. Results showed that the area's elevation ranges between 254 to $3622 \mathrm{~m}$ (AMSL) with an average of $1212 \mathrm{~m}$ (AMSL) as shown in Figure 1. The DEM was divided into five classes. The area between any two adjacent DEM classes was determined and the average weighted elevation for each watershed was calculated using the measurement tool of the GIS.

The Details of the average elevation for the study area are shown in Table 1. The average weighted elevation for each watershed was calculated as follows:

$$
E_{a}=\frac{\sum_{i=1}^{n} E_{i} A_{i}}{\sum_{i=1}^{n} A_{i}}
$$

where, $E_{a}$ is the weighted average elevation, $\mathrm{m}$ (AMSL); $E_{i}$ is the average DEM for each subdivision, $\mathrm{m}$ (AMSL); $A_{i}$ is the subdivision of $i$ th sub-catchment area, $\mathrm{km}^{2} ; n$ is total of sub-catchments. The calculated total watershed area is $50,965 \mathrm{~km}^{2}$. This watershed was originally designated for the Mosul Dam. Currently, it is divided between the Mosul and Ilisu Dams. The larger part of the divided watershed is allocated for the Ilisu Dam from the hydrological point of view. The total watershed's area calculated by this study is very close to the watershed's area calculated by Saleh [26]. 


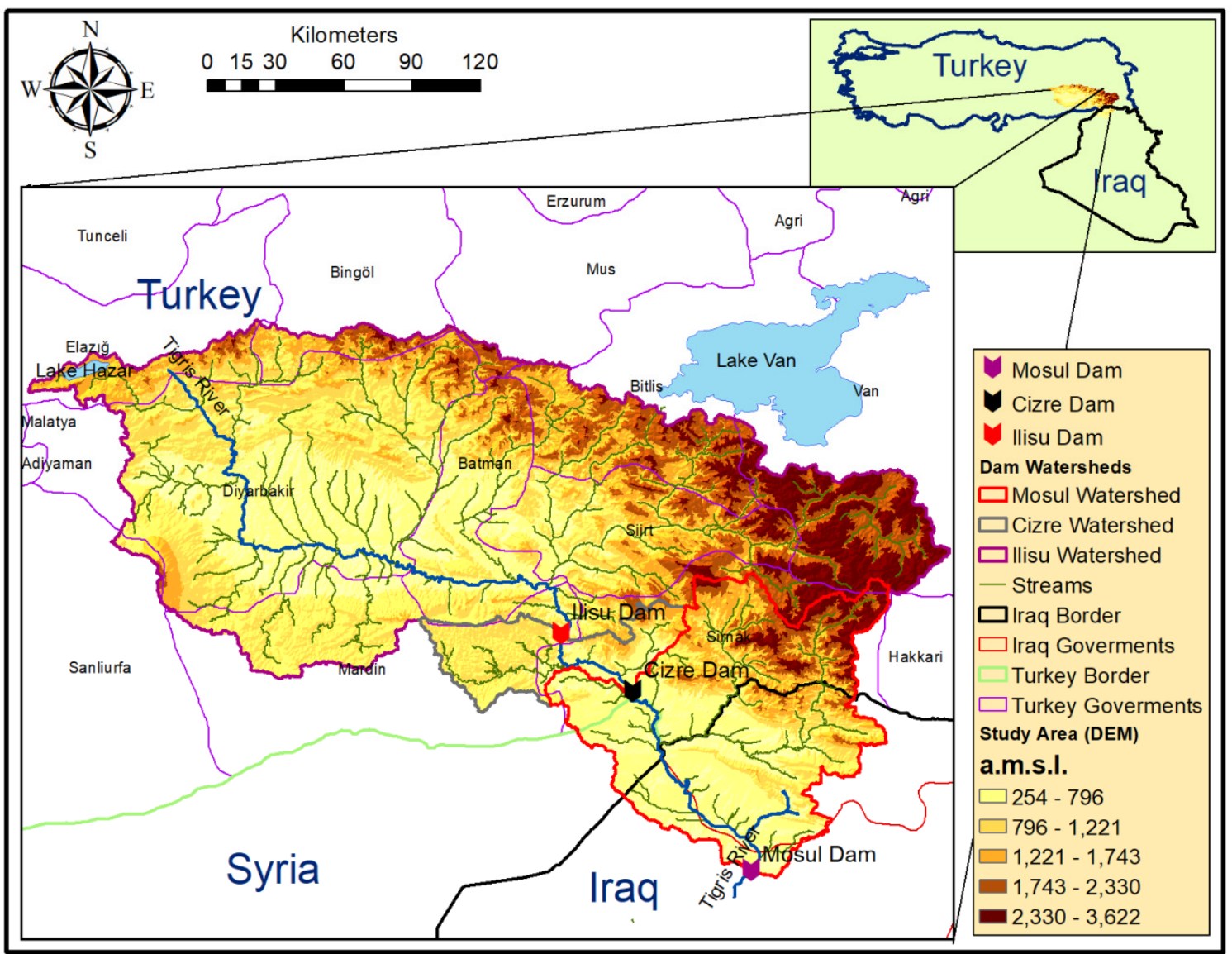

Figure 1. Study area and location of Mosul, Cizre and Ilisu Dams and the digital elevation model (DEM) of the studied watersheds.

Table 1. Digital elevation model (DEM) and annual precipitation isolated for catchment areas that proposed in this study.

\begin{tabular}{cccc}
\hline \multirow{2}{*}{$\begin{array}{c}\text { Digital Elevation Model (DEM), } \\
\text { m (AMSL) }\end{array}$} & $\begin{array}{c}\text { Area of the Original } \\
\text { Watershed, } \mathbf{k m}^{\mathbf{2}}\end{array}$ & \multicolumn{2}{c}{ Total Catchment Area, $\mathbf{~ k m}^{\mathbf{2}}$} \\
\cline { 3 - 4 } & 14980 & Mosul Watershed & Cizre and Ilisu Watersheds \\
\hline $254-796$ & 16779 & 1986 & 10164 \\
\hline $797-1221$ & 8679 & 2213 & 14793 \\
\hline $1222-1743$ & 6249 & 1210 & 6466 \\
\hline $1744-2330$ & 4278 & 893 & 5039 \\
\hline $2331-3622$ & 50965 & 11118 & 3385 \\
\hline Total km2 & 1239 & 1164 & 39847 \\
\hline Average DEM, m (AMSL) & & & 1260 \\
\hline Annual Precipitation Isolated, & & 4411 & \\
mm & 28363 & 3718 & 4829 \\
\hline $601-700$ & 8547 & 2989 & 8498 \\
\hline $701-800$ & 11487 & 0 & 2569 \\
\hline $801-900$ & 2569 & 11118 & 39847 \\
\hline $901-1000$ & 50965 & 737 & 724 \\
\hline Total km ${ }^{2}$ & 727 & & \\
\hline Average precipitation, mm & & & \\
\hline
\end{tabular}


Terrain slope for study area as well as for each watershed was obtained using the surface function in the "Spatial Analyst Tools". The input raster was the DEM and the output raster was measured in degrees. The resulted general slope is running towards the Tigris River (Figure 2). The total terrain slope was subdivided into two classes and ranged from 0 to 90 degrees based on natural breaks. The highest slope average is 89.2 degrees. Small pockets of the watershed have a zero slope, located around the Mosul Dam's Reservoir and Lake Hazar as shown in Figure 2. No major changes in the slope have been deducted between the total watershed and the individual sub-watersheds. The total length of the part of the Tigris River within the studied watershed is about $496.2 \mathrm{~km}$ with an elevation of $263 \mathrm{~m}$ to $976 \mathrm{~m}$ (AMSL). The slope of this part of the river is between 0.0007 and 0.0160 with an average of 0.005 .

Rainfall distribution was obtained from a publication by the UN-ESCWA and BGR [27]. A regional annual average precipitation isohyetal map imposed on the entire watershed area. The area between any two adjacent isohyets was determined for the purpose of calculating the average regional precipitation. Details of the calculations' results are presented in Table 1 . The average regional precipitation for each watershed was calculated as follows:

$$
P_{a}=\frac{\sum_{i=1}^{n} P_{i} A_{i}}{\sum_{i=1}^{n} A_{i}}
$$

where, $P_{a}$ is the average regional precipitation, $\mathrm{mm}$; and $P_{i}$ is the average regional precipitation of the $i$ th area (between two adjacent isohyetals). The average regional precipitations were 727,737 and $724 \mathrm{~mm}$ for the whole watershed (design watershed), the Mosul Dam watershed, and the Ilisu-Cizre Dams watershed, respectively, (Table 1).

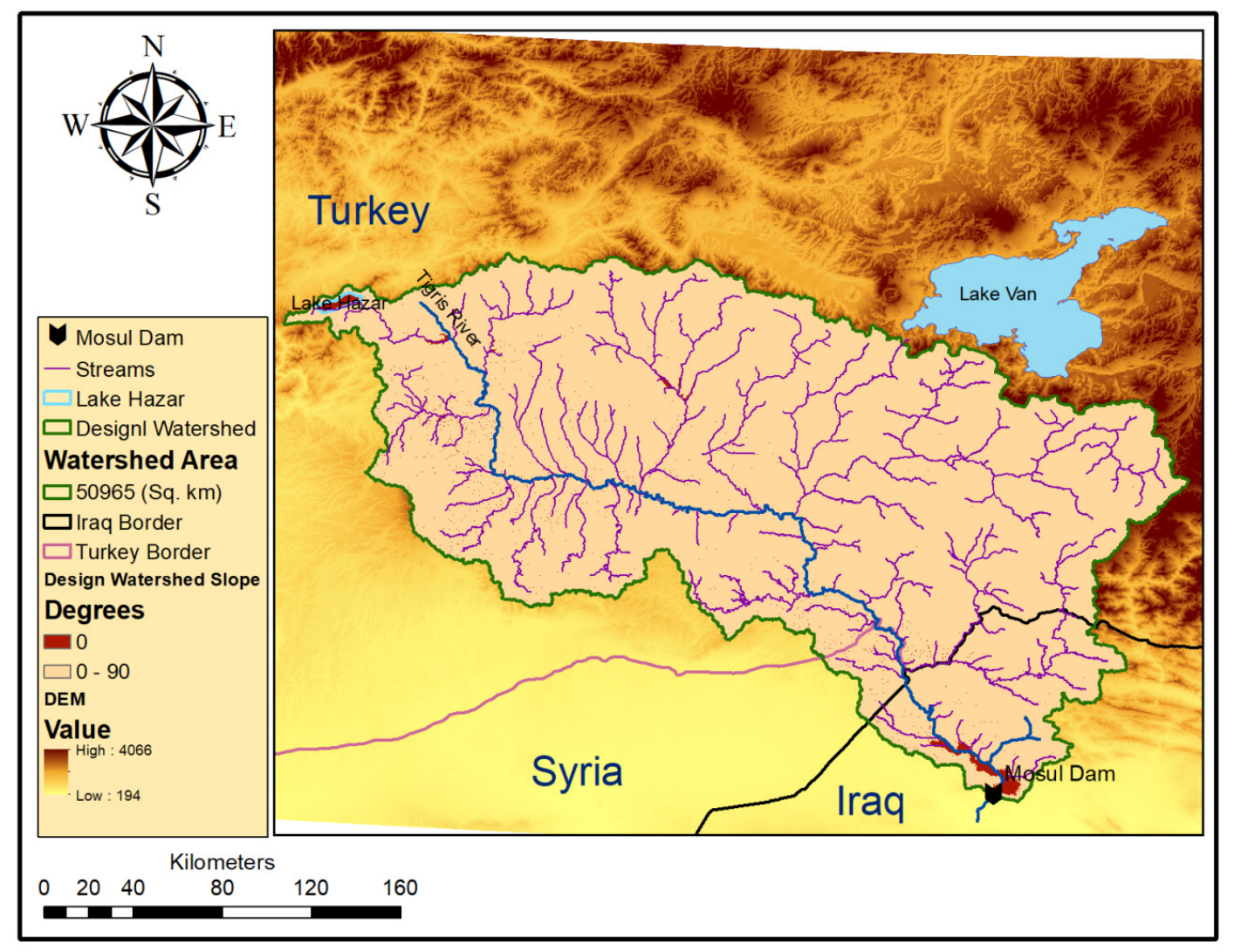

Figure 2. The Mosul Dam watershed prior to the initiation of Cizre and Ilisu Dams and characteristics of terrain slope of study area. This is the designed watershed as of 1986. 


\subsection{Inflow Calculations and Statistical Analysis}

Observed inflow data to the Mosul Dam's Reservoir was obtained from the MoWR. The data is for a period of 30 years (October 1987 to September 2016). The inflow data were subjected to statistical analyses, mainly a probability distribution and a regression analysis. Statistical parameters (statistics) for observed inflows are presented in Table 2. The statistics include the mean, the standard deviation, the maximum, the minimum, the median, the 25 th percentile and the 75 th percentile of the observed data. There are several probability distributions to describe the observed data for monthly inflow estimations such as the normal, the long-normal, the Pearson Type III, the Weibull and the Gumbel's extreme values. The Weibull method [28] distribution was selected because it gave reasonable fit to the observed inflow flow data. The Weibull approach employed in this paper is based on the probability of occurrence of a flood (having a recurrence interval of $T_{r}$ ) in any year by calculated the probability of exceedance as follows:

$$
P_{p}=\frac{m}{N+1}
$$

where, $P_{p}$ is the probability of exceedance; $m$ is order or rank of the event; and $N$ is number of events (data points). The Weibull method was applied for the monthly flows for the period of record using Equation (3). Graphs of exceedance probability for each month are presented in Figure 3.

Table 2. Details of statistical description and regression analysis for observed inflow data of years (1987-2016) for the Mosul Dam Reservoir $(N=30)$.

\begin{tabular}{|c|c|c|c|c|c|c|c|c|c|c|c|c|}
\hline $\begin{array}{l}\text { Statistical } \\
\text { Description }\end{array}$ & Oct & Nov. & Dec. & Jan. & Feb. & March & April & May & June & July & Aug. & Sept. \\
\hline $\begin{array}{c}\text { Mean } \\
(\mathrm{m} 3 / \mathrm{sec})\end{array}$ & 159 & 283 & 402 & 486 & 648 & 985 & 1493 & 1163 & 499 & 231 & 153 & 128 \\
\hline Std. Dev. & 55 & 162 & 316 & 305 & 306 & 392 & 638 & 619 & 268 & 99 & 58 & 37 \\
\hline $\begin{array}{l}\text { Maximum } \\
\text { (m3/sec) }\end{array}$ & 357 & 690 & 1665 & 1330 & 1265 & 2222 & 3275 & 3260 & 1329 & 584 & 298 & 195 \\
\hline $\begin{array}{l}\text { Minimum } \\
(\mathrm{m} 3 / \mathrm{sec})\end{array}$ & 78 & 95 & 122 & 156 & 194 & 360 & 502 & 345 & 160 & 77 & 59 & 64 \\
\hline $\begin{array}{l}\text { Median } \\
\text { (m3/sec) }\end{array}$ & 148 & 244 & 323 & 417 & 629 & 956 & 1332 & 1023 & 445 & 233 & 141 & 124 \\
\hline $25 \%$ & 120 & 163 & 217 & 238 & 388 & 665 & 1058 & 749 & 368 & 156 & 106 & 98 \\
\hline $75 \%$ & 179 & 365 & 470 & 736 & 944 & 1191 & 1924 & 1433 & 590 & 262 & 198 & 156 \\
\hline \multicolumn{13}{|c|}{ Regression Analysis } \\
\hline$a$ & 0.005 & 0.013 & 0.018 & $0.023^{\circ}$ & 0.028 & 0.035 & 0.058 & 0.047 & 0.02 & 0.008 & 0.005 & 0.004 \\
\hline$b$ & 0.011 & 0.019 & 0.021 & 0.022 & 0.019 & 0.014 & 0.016 & 0.017 & 0.017 & 0.014 & 0.014 & 0.010 \\
\hline $\begin{array}{c}\text { Coefficient of } \\
\text { determination, } \mathrm{R}^{2}\end{array}$ & 0.90 & 0.97 & 0.92 & 0.98 & 0.94 & 0.95 & 0.94 & 0.92 & 0.92 & 0.87 & 0.97 & 0.98 \\
\hline
\end{tabular}

Yihdego and Webb [14] discussed the land use change and reduction in runoff using water balance model (modified tanh equation). The modified tanh equation is expressed as follows:

$$
Q=H+R S-V \tanh \left(\frac{R S}{V}\right)
$$

where, $Q$ is the predicted monthly flow; $H$ is the median monthly base flow; $R S$ is cumulative surplus rainfall (monthly rainfall subtracting to the monthly evapotranspiration); and $V$ is a value to determine the shape of the tanh curve and can be computed by fitting the tanh curve to the observed data. The modified tanh equation as well as the original tanh model were derived to establish runoff rainfall relationship. The modified tanh equation intended to predict runoff changes associated with changes in land use. Therefore, Equation (4) could not account for changes in watershed area; area reduction as is the problem of the present paper. Accordingly, the modified tanh equation cannot be utilized for watersheds of this study. Thus, a regression model is more suitable to predict runoff instead of Equation (4). 
Regression equations were generated to estimate monthly and annual flows based on results of Figure 3. The derived equations are based on the area of the studied watershed. The USGS [29] developed regional regression equations for estimating magnitude and frequency of runoffs for ungagged sites across some watersheds in the USA. In the same approach, the general form of the derived equations in this study is expressed as:

$$
Q=a A \exp \left(-b P_{p}\right)
$$

where, $Q$ is the estimated monthly flow, $\mathrm{m}^{3} / \mathrm{sec} ; a$ is the coefficient of the regression model; $b$ is the exponent of the regression model; and $A$ is the catchment area, $\mathrm{km}^{2}$.

a)

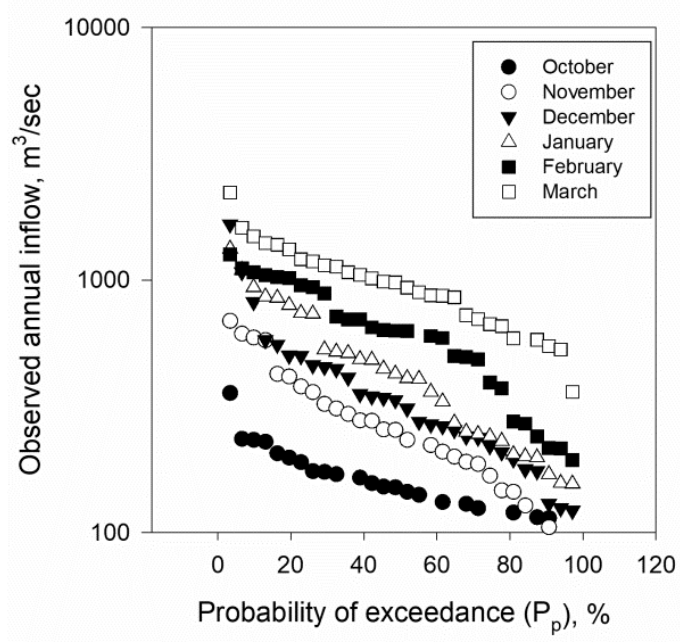

b)

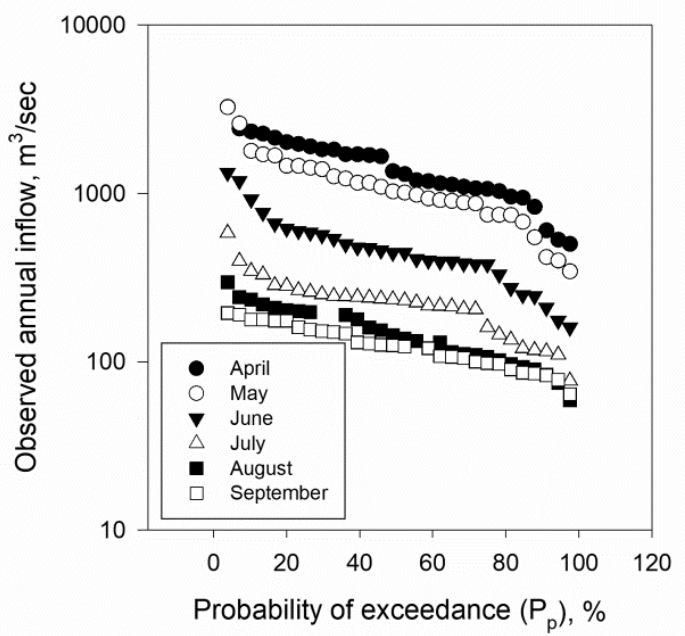

Figure 3. Observed annual inflow frequency curves for each month: (a) From October to March and (b) From April to September (for the years 1987-2016).

The parameters $a$ and $b$ were derived for each month and listed in Table 2. The above findings were applied to predict flows to the Mosul Reservoir following the full operation of the Ilisu-Cizre scheme. Since, Equation (5) is based on one main variable (the catchment area, $A$ ); it is reasonable to apply it to any part of the studied watershed, considering the divide watershed that still has the same average DEM, slope and precipitation. The pre-Ilisu inflow is the observed inflow for the last 30 years (results from Figure 3). The generated-post-Ilisu inflow (proposed in this study) is the predicted inflow to the Mosul Dam using Equation (5) after the full operation of Ilisu-Cizre scheme. The generated post-Ilisu inflow was statistically compared with as the post-Ilisu inflow predicted by Declaration et al. [13] study.

The computed statistical differences in regression equations, observed inflow data, generated-post-Ilisu by this study, the Declaration et al. [13] study inflows were examined using the analysis of variance (ANOVA) technique within SigmaPlot 13.5 Software. A one-way ANOVA was utilized to describe and compare the data with basic statistics for data with more than two groups. A one-way ANOVA reported the mean, standard deviation, maximum, minimum, median, 25\% and $75 \%$ of the observed data. The pairwise comparisons of t-tests are calculated to compare the regression equations, observed inflow data, generated-post-Ilisu, Declaration et al. inflows using the Tukey test method. The ANOVA is considered a significant difference when the level of $\alpha$ is equal or less than 0.05 [30-32]. 


\section{Results and Discussion}

\subsection{Watershed and Precipitation Distribution Analysis}

The original watershed area for the Mosul Dam as listed in the design report is 54,900 $\mathrm{km}^{2}$ [26]. This watershed area includes all the watershed of the Tigris River upstream of Mosul Dam. The Mosul Dam watershed area was calculated for this paper using ArcMap GIS is 50,965 km² (Figure 2). The Mosul Dam watershed area, however, is now reduced by the newly constructed Ilisu Dam. As calculated for this paper, the area contributing flow to the Ilisu Dam is estimated as $37,064 \mathrm{~km}^{2}$ (Figure $4 \mathrm{a}$ ). It is about $73 \%$ of the original Mosul Dam watershed. If both the Ilisu and the Cizre Dams are jointly considered, the total watershed area that will be subtracted from the Mosul Dam watershed increased to $39,847 \mathrm{~km}^{2}$ (Figure $4 \mathrm{~b}$ ).

a)

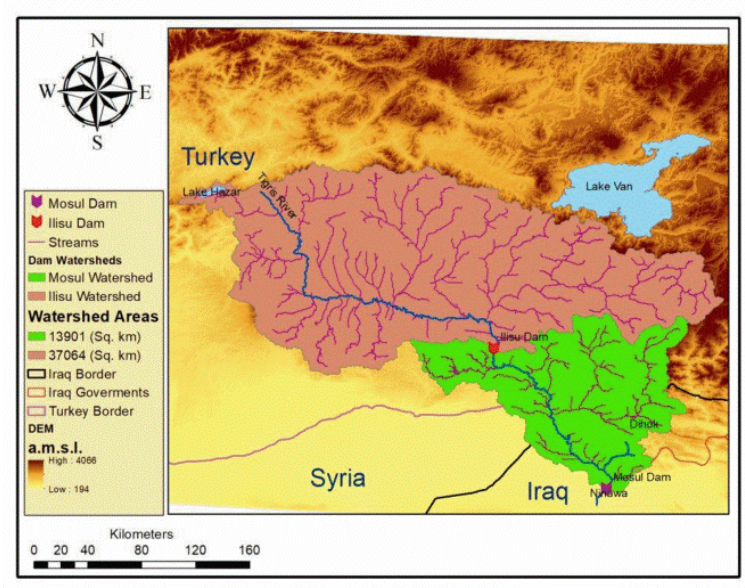

b)

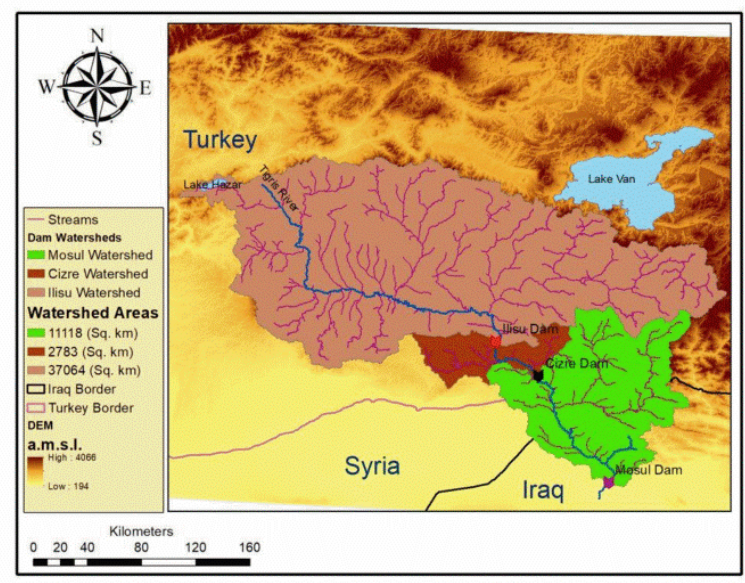

Figure 4. Reduction on the Mosul Dam watershed; (a) in presence of the Ilisu Dam and (b) in presence of the Cizre and Ilisu Dams.

The DEM of the study area is between 254 to $3622 \mathrm{~m}$ (AMSL) and divided into five classes based on natural breaks via GIS (Figure 1). The DEM does not reveal significant differences in the weighted average throughout the study area. Most of the watershed areas fall within the 254-796 and 797-1221 m (AMSL). Small area of high elevation of 1744-3622 m (AMSL) located in the north-eastern strip of Ilisu Dam's watershed. The highest elevation within the Mosul Dam's watershed is 2331-3622 m (AMSL) (Table 1 and Figure 1). The average elevation for the entire watershed (Ilisu and Mosul) is about $1239 \mathrm{~m}$ (AMSL) (Table 1). According to Table 1, no statistical differences of average elevation were found between the original watershed versus the Mosul Dam watershed and the Ilisu-Cizre Dam watershed with $p$-value of 0.40 . Hence, it is reasonable to conclude that elevations are equally distributed over the two watersheds (Ilisu and Mosul). It is concluded that elevations have no major influences that could edge the generated outflow from either watershed. The highest slope of the original watershed is between 88 to 90 degrees with an average of 89.2 degrees (Figure 2). Similar to DEM analysis, the average slope of 89.2 degrees does not change for the separated watersheds (Mosul Dam watershed versus the Ilisu-Cizre Dam watershed).

Analysis of areal precipitation distribution on the whole watershed does not reveal significant changes in the annual mean values throughout the area. Most of the watershed's precipitation falls within 601-700 mm/year. Small area of high precipitation $(901-1000 \mathrm{~mm})$ is found in the northern strip of the Ilisu Dam watershed. The highest rate of precipitation within the Mosul Dam watershed is 701-800 $\mathrm{mm}$ (Table 1 and Figure 5). The average regional precipitation for the entire watershed is about $727 \mathrm{~mm} /$ year. For the Mosul Dam watershed, it is about $737 \mathrm{~mm} /$ year and for the Ilisu-Cizre watershed is about $724 \mathrm{~mm} /$ year (Table 1). The difference on precipitation rates between the separated 
watersheds is not significant. Moreover, no statistical differences of average regional precipitation were found between the whole watershed (as one unit) and the separated watersheds with a $p$-value of 0.424 . Hence, it is reasonable to conclude that precipitation rates are equally distributed over the two watersheds (Ilisu-Cizre and Mosul). It is anticipated that precipitation rates will not edge the generated discharge for either dam.

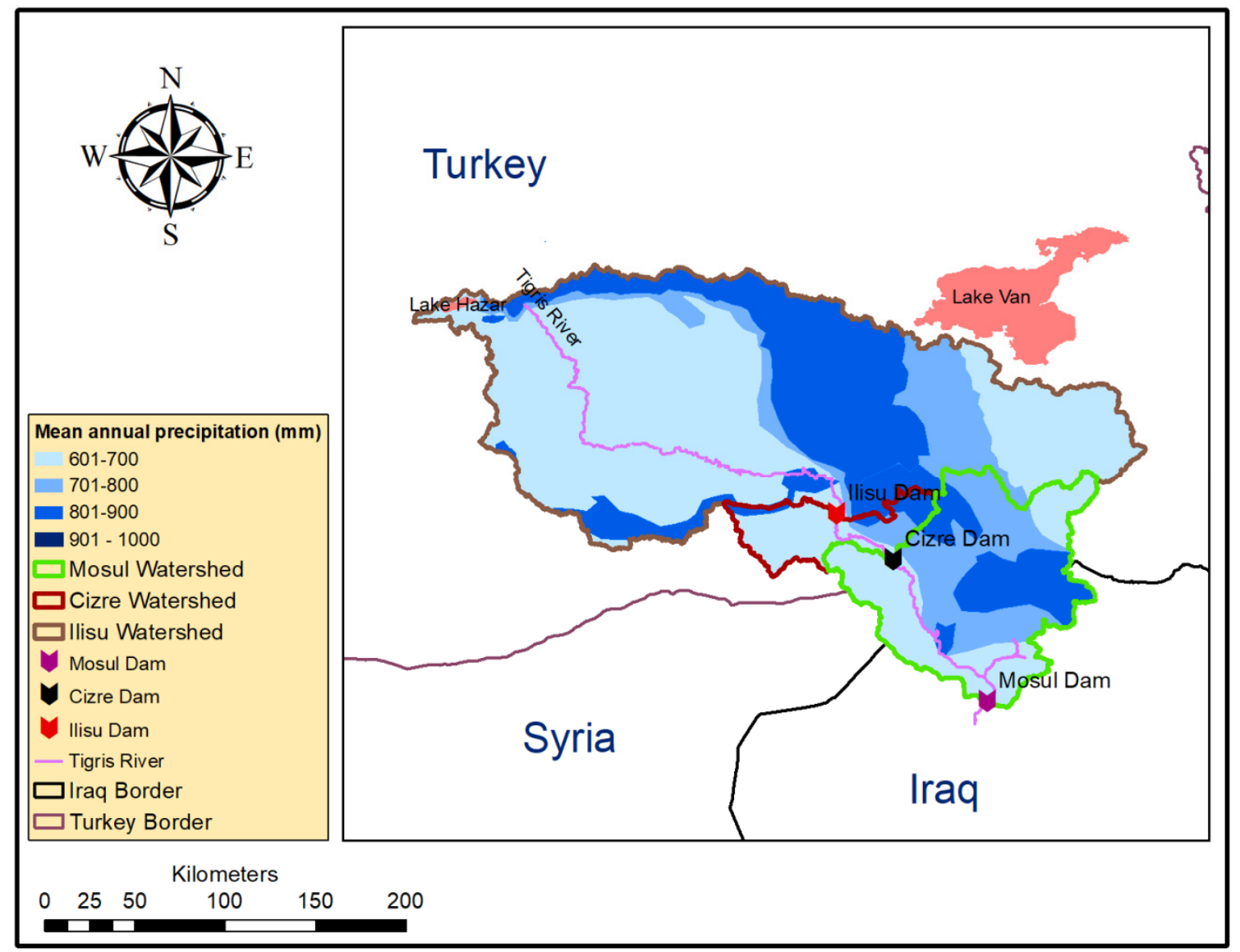

Figure 5. The annual precipitation distribution on the studied watersheds (Mosul, Cizre and Ilisu).

In general, no major influences of elevation, terrain slope and annual precipitation rates variations on generated outflow from either watershed. It follows that the watershed area is the only controlling factor of the basin outflow. Rahi et al. [1] quantified the runoff of eight catchment areas in eastern Iraq using regression equations derived for areas in the western and southern parts of the USA. Rahi et al. [1] used several models based on the catchment area location, average terrain elevation, average annual precipitation and slope of mainstream. The authors found that the regression equations that have catchment areas as the sole variable give reasonable results with no statistically significant differences. Thus, the regression equation that was derived from Figure 3 and Table 2 (i.e., Equation (5)) is proposed in this study to calculate the generated-post-Ilisu inflow.

\subsection{Inflow to the Mosul Dam}

The historical inflow data entering Mosul Dam Reservoir were subjected to statistical descriptive analyses as shown in Table 2. A maximum inflow of $3260 \mathrm{~m}^{3} / \mathrm{s}$ was recorded in 1993, while a minimum inflow of $64 \mathrm{~m}^{3} / \mathrm{s}$ in 1991. The highest monthly mean inflow (for the period of record) is $1493 \mathrm{~m}^{3} / \mathrm{s}$ and it is for the month of April, while the lowest monthly average inflow is $128 \mathrm{~m}^{3} / \mathrm{s}$ occurred in September. The highest 25\% and 75\% inflows were 1058 and $1924 \mathrm{~m}^{3} / \mathrm{s}$, respectively, both recorded in April. The lowest 25\% and $75 \%$ inflows were 98 and $156 \mathrm{~m}^{3} / \mathrm{s}$, respectively, both recorded in September. 
It can be concluded that the highest and the lowest inflows (for the record period of 30 years) occurred in April and September, respectively. The parameters $a$ and $b$ of Equation (5) were derived for each month based on regression equations of Figure 3, as shown in Table 2.

The pre-Ilisu Dam operation flow analyses results represent the current status of the Mosul Dam inflow (Figure 6). The current mean annual inflow for the dam is about $552 \mathrm{~m}^{3} / \mathrm{sec}$; the inflow that is available $95 \%$ of the time is about $267 \mathrm{~m}^{3} / \mathrm{sec}$ (practically the minimum flow for the period of record). The Mosul Dam has operated well for the last three decades on this inflow. The modelled pre-Ilisu Dam was generated from a regression model (Equation (5)) using 0.019 and 0.013 for the parameters $a$ and $b$, respectively. These values were derived based on the mean annual inflow for the period of record. The analysis of variance (ANOVA) technique reported the mean, median, $25 \%$ and $75 \%$ of 552 and $544 \mathrm{~m}^{3} / \mathrm{sec}, 549$ and $509 \mathrm{~m}^{3} / \mathrm{sec}, 384$ and $368 \mathrm{~m}^{3} / \mathrm{sec}$ and 624 and $705 \mathrm{~m}^{3} / \mathrm{sec}$, for predicted and observed pre-Ilisu Dam operation, respectively. The t-test of pairwise compression indicated that there is no significant difference between predicted versus observed pre-Ilisu Dam inflow with $p$-value of 0.886 .

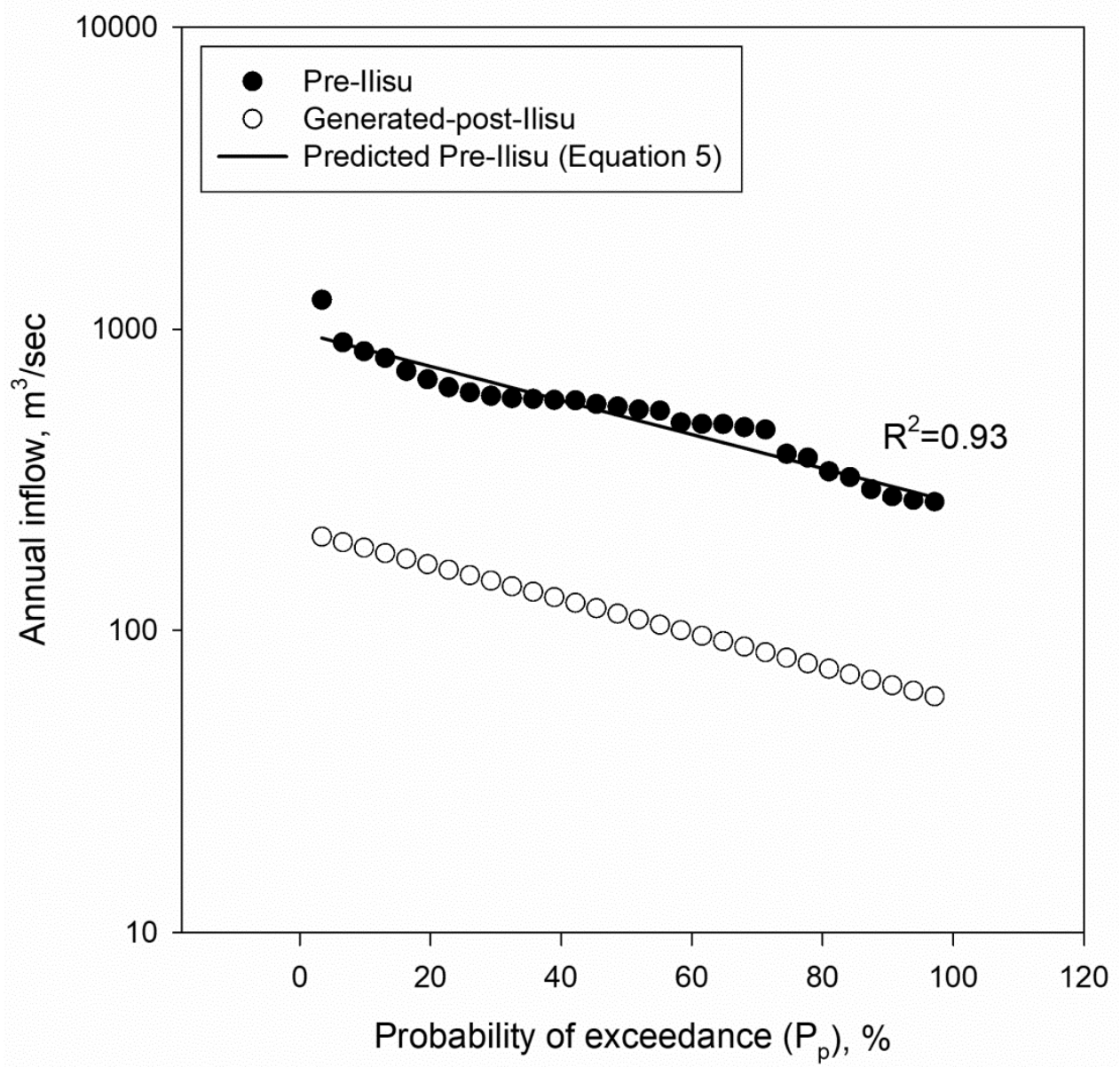

Figure 6. The annual inflow to the Mosul Dam Reservoir; the pre-Ilisu operation is the observed inflow for the last 30 years; the generated post-Ilisu operation is the inflow regime predicted by this study after the full operation of the Ilisu and Cizre Dams; and the modeled pre-Ilisu operation (Equation (5)).

When the Ilisu and Cizre Dams start their normal operation, the situation in Mosul Dam will be negatively affected. The generated post-Ilisu-Cizre operation data were obtained based on a regression model (Equation (5), using parameters $a$ and $b$ of 0.019 and 0.013 , respectively) of the reduced watershed area (Figure 6). Results from Figure $4 \mathrm{~b}$ show that the area of the Tigris River basin that will contribute direct runoff to the Mosul Dam is about $22 \%$ of the original watershed (i.e. the current one). The expected mean annual inflow will be reduced to about $119 \mathrm{~m}^{3} / \mathrm{sec}$ and the flow that will be 
available $95 \%$ of the time is about $61 \mathrm{~m}^{3} / \mathrm{sec}$ (represented the minimum flow) (Figure 6). This future minimum inflow is equal to the environmental flow $\left(60 \mathrm{~m}^{3} / \mathrm{sec}\right)$ that is the only flow that Turkey is committed to release post-Ilisu-Cizre operation [13]. However, it is so small that it practically turns Mosul Dam inoperable.

The observed mean monthly pre-Ilisu and generated-post-Ilisu inflows to the Mosul Dam were compared to inflows predicted and reported by Declaration et al. [13] (Figure 7). The latter is about 33\% of the current observed flow. Not only the flow is reduced, there is zero flow that lasts for four months (June to September). The zero flow is a result of the whole flow was diverted away within Turkey [13]. This result is an indication to the fact that it is quite possible that Turkey may divert more water and the zero flow may last longer than the four months mentioned by Declaration et al. [13] study.

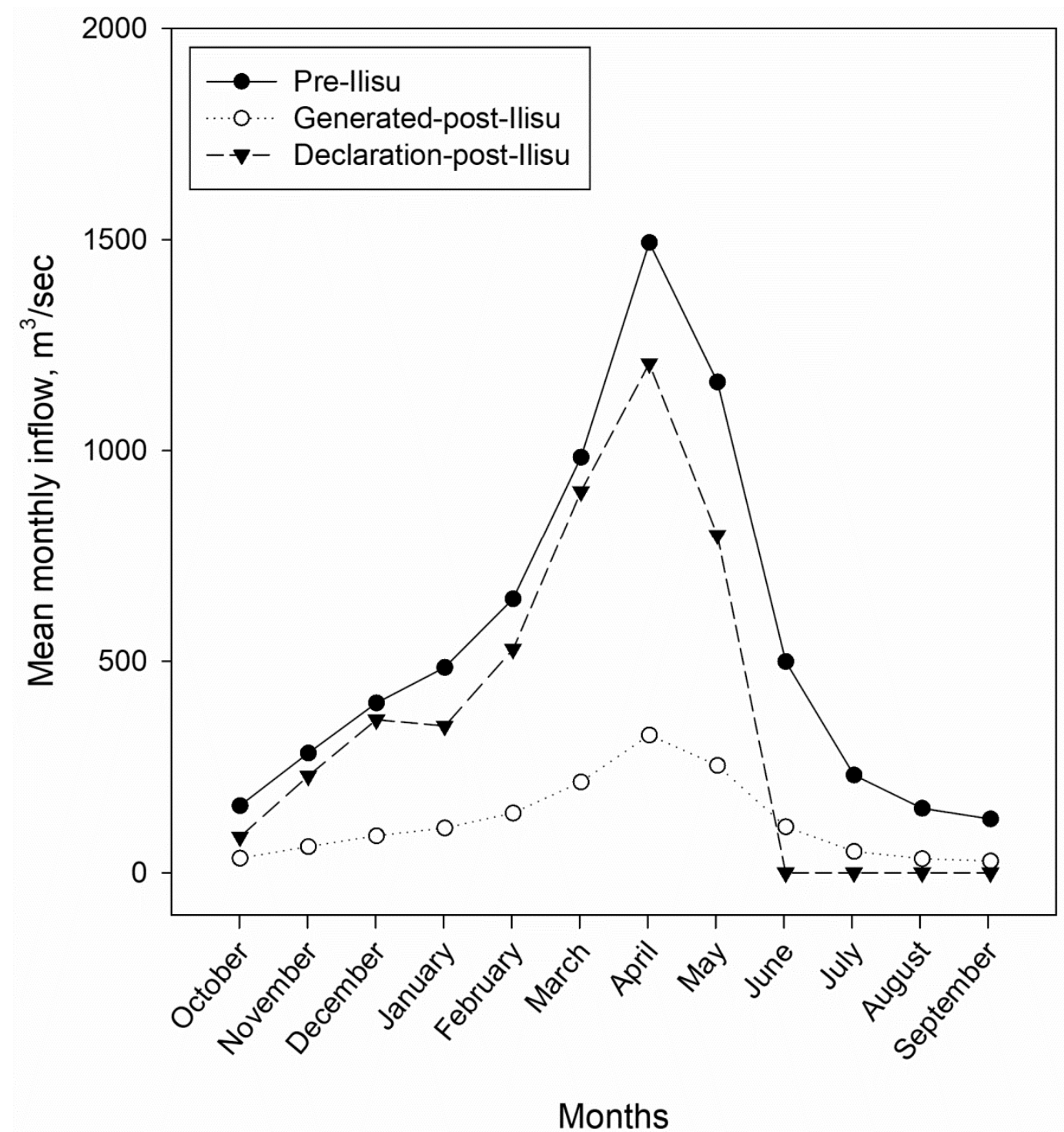

Figure 7. Reduction Mean monthly inflow to the Mosul Dam; The pre-Ilisu is the observed inflow for the last 30 years; The generated- post-Ilisu is the mean monthly inflow following the operation of Ilisu and Cizre Dams as predicted by this paper; The the mean monthly inflow following the operation of Ilisu and Cizre Dams as predicted by Declaration et al. [13].

The analysis of variance (ANOVA) technique reported the mean and standard deviation of 552, 121 , and $371 \mathrm{~m}^{3} / \mathrm{sec}$, and 443,97 and $409 \mathrm{~m}^{3} / \mathrm{sec}$ for pre-Ilisu, generated-post-Ilisu and the predicted by Declaration et al. [13] study, respectively. The pairwise compression using Tukey test indicated 
that there is a significant difference between generated-post-Ilisu versus post-Declaration-Ilisu inflows with $p$-value of 0.015 . It should be indicated that the Declaration-post Ilisu is a release from the Ilisu Reservoir according to a specific scenario outlined by the authors [13]. This release is quite different from the inflow from the reduced watershed which is the subject matter of this paper. This difference between the two approaches may explain the significant statistical difference between the post-Ilisu flows mentioned earlier. The mean annual cumulative inflow to the Mosul Reservoir in the case of generated-post-Ilisu (this study) is $4.6 \mathrm{bcm}$ : a little more than the dead storage of Mosul Reservoir. This paper findings stress that, unless the two riparian countries (Turkey and Iraq) reach a mutual understating and share the water resources of the Tigris River reasonably, Iraq may face the severe reduction in inflow rates to the Mosul Dam (i.e. the worst scenario flow outlined throughout the paper). The flow that is reliable to the Mosul Dam is only $22 \%$ of the observed current flow. Furthermore, the flow adapted by this paper may be less than the environmental flow committed by Turkey $\left(60 \mathrm{~m}^{3} / \mathrm{sec}\right)$ for some months of the year.

\section{Conclusions}

The Southeastern Anatolia Project (Turkish Language acronym GAP) is a Turkish water resources project that is initiated and built in the upper Euphrates and Tigris basins (upper Mesopotamia). The scheme includes at least 22 dams on both rivers. The latest of these dams is the Ilisu Dam. The Ilisu Dam is located on the Tigris River, $65 \mathrm{~km}$ upstream from the border line between Turkey and Syria. The dam is intended for hydroelectric power generation and will be followed by another regulator dam (Barrage) at Cizre. The latter is used for irrigation purposes. Cizre Dam is to be constructed $45 \mathrm{~km}$ downstream of Ilisu Dam and about $20 \mathrm{~km}$ upstream of the border line between Turkey and Iraq.

The Ilisu Dam, being upstream from the existing Mosul Dam of Iraq, will drain the majority of the Mosul Dam's watershed. The original designed Mosul Dam watershed (area is 54,900 $\mathrm{km}^{2}$ ) will be reduced to about one fifth of the total area. The original Mosul Dam's watershed area as calculated for this paper is $50,965 \mathrm{~km}^{2}$. The area contributing flow to the Ilisu Dam as calculated by this paper is about $37,064 \mathrm{~km}^{2}$. If both Ilisu and Cizre Dams are jointly considered, the total watershed area that will be subtracted from Mosul Dam Watershed is about $39,847 \mathrm{~km}^{2}$. A point should be clarified regarding the stability dam is that recent information indicates that the dam stability has been improved considerably; that the dam reached its sixth-highest pool of record in April 2019 and showed no signs of distress.

The worst-case scenario approach was employed to estimate the reduction of Mosul's Dam flow resulting from the full operation of the Ilisu-Cizre system. The reduced inflow was calculated using a regression model based on observed flow data of 30 years. Results of the regression model show that the inflow to the Mosul Dam will be reduced to about $22 \%$ of the current flow assuming a full operation of the Ilisu-Cizre system. The cumulative flow for the whole year in the average will be about $4.6 \mathrm{bcm}$ : a little more than the dead storage of Mosul Reservoir. The expected mean annual inflow will be reduced to about $119 \mathrm{~m}^{3} / \mathrm{sec}$; the flow that will be available $95 \%$ of the time is about $61 \mathrm{~m}^{3} / \mathrm{sec}$. The mean monthly inflow was generated and found, for some months, to be less than the environmental flow committed by Turkey.

Author Contributions: The performing data analysis, providing required materials, ideas, formulation of overarching research aims, editing of the text; data/evidence collection were performed by A.-S.T.A.-M. and K.A.R.; reviewing similar studies and acquiring required data was the task of W.K.L. All authors have read and agreed to the published version of the manuscript.

Funding: This research received no external funding.

Acknowledgments: The authors acknowledge the Ministry of Water Resources in Iraq for collaboration and providing some flowrate data. The authors also acknowledge Mustansiriyah University (www.uomustansiriyah. edu.iq) for the support and helping throughout the development of this paper.

Conflicts of Interest: The authors declare no conflict of interest. 


\section{References}

1. Rahi, K.A.; Al-Madhhachi, A.T.; Al-Hussaini, S.N. Assessment of surface water resources of eastern Iraq. Hydrology 2019, 6, 57. [CrossRef]

2. Al-Madhhachi, A.T.; Al-Mussawy, H.A.; Basheer, M.I.; Abdul-Sahib, A.A. Quantifying Tigris riverbanks stability of southeast Baghdad city using BSTEM. Int. J. Hydrol. Sci. Technol. 2020. [CrossRef]

3. Partow, H. The Mesopotamian Marshlands: Demise of an Ecosystem Early Warning and Assessment; Division of Early Warning and Assessment, United Nations Environment Program: Nairobi, Kenya, 2001.

4. Rahi, K.A.; Halihan, T. Changes in the salinity of the Euphrates River system in Iraq. Reg. Environ. Chang. 2010, 10, 27-35. [CrossRef]

5. Bilgen, A. The Southeastern Anatolia Project (GAP) in Turkey: An alternative perspective on the major rationales of GAP. J. Balk. Near East. Stud. 2019, 21, 532-552. [CrossRef]

6. Kolars, J. Problems of International River Management: The Case of the Euphrates, 2nd ed.; International waters of the Middle East—from Euphrates-Tigris to Nile; Oxford University Press: London, UK, 1994; pp. 44-94.

7. Aydin, M.; Ulu, A.; Karaduman, C. CFD Analysis of Ilısu Dam Sluice Outlet. Firat Univ. Turk. J. Sci. Technol. 2018, 13, 119-124.

8. Aydin, M.; Ulu, A.; Karaduman, C. Investigation of aeration performance of Ilısu Dam outlet using two-phase flow model. Appl. Water Sci. 2019, 9, 111. [CrossRef]

9. Yalcin, E.; Tigrek, S. Hydropower production without sacrificing environment: A case study of Ilisu Dam and Hasankeyf. Int. J. Water Resour. Dev. 2016, 32, 247-266. [CrossRef]

10. Yalcin, E.; Tigrek, S. The Tigris hydropower system operations: The need for an integrated approach. Int. J. Water Resour. Dev. 2019, 35, 110-125. [CrossRef]

11. Kitchen, W.H.; Ronayne, M. The Ilisu Dam Environmental Impact Assessment Report: Review and critique. Public Archaeol. 2002, 2, 101-116. [CrossRef]

12. Rahi, K.A.; Halihan, T. Salinity evolution of the Tigris River. Reg. Environ. Chang. 2018, 18, $2117-2127$. [CrossRef]

13. Declaration, B.; Williams, P.B.; Frucht, S.B. A Review of the Hydrologic and Geomorphic Impacts of the Proposed Ilisu Dam. Available online: http://www2.weed-online.org/uploads/PWA_Ilisu_Report.pdf (accessed on 10 March 2016).

14. Al-Ansari, N.; Issa, I.E.; Sissakian, V.; Adamo, N.; Knutsson, S. Mystery of Mosul Dam the most dangerous dam in the world: The project. J. Earth Sci. Geotech. Eng. 2015, 5, 15-31.

15. Rahi, K.A. Salinity management in the Shatt Al-Arab River. Int. J. Eng. Technol. 2018, 7, 128-133. [CrossRef]

16. Mosul, D. Wikipedia. Available online: https://en.wikipedia.org/wiki/Mosul_Dam (accessed on 28 February 2020).

17. Al-Taiee, T.M.; Rasheed, A.M. Simulation Tigris River Flood Wave in Mosul City Due to a Hypothetical Mosul Dam Break. Damascus Univ. J. 2009, 25, 17-36.

18. Mosul Dam Task Force Declares: Mission Complete, Departs Iraq. Mosul Dam Task Force Program Office. Available online: https://www.defensemedianetwork.com/stories/mosul-dam-task-force-declares-missioncomplete-departs-iraq/ (accessed on 27 February 2020).

19. Bosshard, P.; Declaration, B. Ilisu-a Test Case of International Policy Coherence. Available online: https: //www.rivernet.org/turquie/ilisu.htm (accessed on 5 May 2019).

20. Yihdego, Y.; Webb, J.A. An empirical water budget model as a tool to identify the impact of land-use change in stream flow in southeastern Australia. Water Resour. Manag. J. 2013, 27, 4941-4958. [CrossRef]

21. Yihdego, Y.; Webb, J.A. Assessment of wetland hydrological dynamics in a modified catchment basin: Case of Lake Buninjon, Victoria, Australia. Water Resour. Manag. J. 2017, 89, 144-154. [CrossRef]

22. Yihdego, Y.; Khalil, A.; Salem, S.H. Nile River's Basin Dispute: Perspectives of the Grand Ethiopian Renaissance Dam (GERD). Glob. J. Hum. Soc. Sci. 2017, 17, 1-21.

23. Yihdego, Y.; Reta, G.; Becht, R. Human impact assessment through a transient numerical modelling on The UNESCO World Heritage Site, Lake Navaisha, Kenya. Environ. Earth Sci. 2017, 76, 9. [CrossRef]

24. Worst-Case. The Merriam-Webster.com Dictionary, Merriam-Webster Inc. Available online: https://www. merriam-webster.com/dictionary/worst-case (accessed on 19 January 2020).

25. United States Geological Survey, Earth Explorer (USGS-EE), 2018. Available online: https://earthexplorer. usgs.gov/ (accessed on 5 January 2019). 
26. Saleh, D.K. Stream Gage Descriptions and Streamflow Statistics for Sites in the Tigris River and Euphrates River Basins, Iraq; US Geological Survey: Reston, VA, USA, 2010.

27. United Nations Economic and Social Commission for Western Asia (UN-ESCWA) and Bundesanstalt für Geowissenschaften und Rohstoffe (BGR). Chapter 3: Tigris River Basin. In Inventory of Shared Water Resources in Western Asia; UN-ESCWA: Beirut, Lebanon, 2013.

28. Barnard, R.W.; Perera, C.; Surles, J.G.; Trindade, A.A. The linearly decreasing stress Weibull (LDSWeibull): A new Weibull-like distribution. J. Balk. Near East. Stud. 2019, 6, 11. [CrossRef]

29. Jennings, M.E.; Thomas, W.O.; Riggs, H.C. Nationwide summary of U.S. In Geological Survey Regional Regression Equations for Estimating Magnitude and Frequency of Floods for Ungaged SITES; USGS Water-Resources Investigations Report: Washington, VA, USA, 1994.

30. Abbas, M.N.; Al-Madhhachi, A.T.; Esmael, S.A. Quantifying soil erodibility parameters due to wastewater chemicals. Int. J. Hydrol. Sci. Technol. 2019, 9, 550-568. [CrossRef]

31. Al-Husseini, T.R.; Al-Madhhachi, A.T.; Hasan, M.B. Laboratory experiments and numerical model of local scour around submerged sharp crested weir. J. King Saud Univ. Eng. Sci. 2020, 32, 167-176. [CrossRef]

32. Al-Madhhachi, A.T.; Mutter, G.M.; Hasan, M.B. Predicting Mechanistic Detachment Model due to Lead-Contaminated Soil Treated with Iraqi Stabilizers. KSCE J. Civil Eng. 2019, 23, 2898-2907. [CrossRef]

(C) 2020 by the authors. Licensee MDPI, Basel, Switzerland. This article is an open access article distributed under the terms and conditions of the Creative Commons Attribution (CC BY) license (http://creativecommons.org/licenses/by/4.0/). 